\title{
Effect of Water Stress on the Growth and Yield of Cotton Crop (Gossypium hirsutum L.)
}

\author{
Arbab Sahito', Zulfiqar Ali Baloch2, Amanullah Mahar,4, Sohail Ahmed Otho5, \\ Shahmir Ali Kalhoro6, Amjad Ali ${ }^{3 *}$, Fahad Ali Kalhoro ${ }^{7}$, Rab Nawaz Soomro ${ }^{8}$, Fayaz Ali ${ }^{3}$ \\ ${ }^{1}$ Department of Agronomy, Sindh Agriculture University, Tando Jam, Pakistan \\ ${ }^{2}$ College of Economics and Management Sciences, Northwest A\&F University, Yangling, China \\ ${ }^{3}$ College of Natural Resources and Environment, Northwest A\&F University, Yangling, China \\ ${ }^{4}$ Centre for Environmental Sciences, University of Sindh, Jamshoro, Pakistan \\ ${ }^{5}$ College of Plant Protection, Northwest A\&F University, Yangling, China \\ ${ }^{6}$ Faculty of Agriculture, Lasbela University of Agriculture, Water \& Marine Sciences, Lasbela, Pakistan \\ ${ }^{7}$ Department of Plant Breeding and Genetics, Sindh Agriculture University, Tando Jam, Pakistan \\ ${ }^{8}$ College of Animal Science and Technology, Northwest A\&F University, Yangling, China \\ Email: ${ }^{*}$ amjadali@aup.edu.pk
}

Received 10 March 2015; accepted 21 April 2015; published 28 April 2015

Copyright (C) 2015 by authors and Scientific Research Publishing Inc.

This work is licensed under the Creative Commons Attribution International License (CC BY). http://creativecommons.org/licenses/by/4.0/

(c) (i) Open Access

\section{Abstract}

Cotton is one of the most important fibre crops playing a key role in economic and social affairs of the world. Water is a critical factor which influences on growth and yield of the cotton crop. Scarcity of water has put tremendous pressure on scientists to introduce drought tolerant cotton varieties. This study was aimed to determine water stress effects on the growth and yield of cotton. The present study was carried out to examine the effect of number of irrigations on the growth and yield of cotton during 2014. The field trial was conducted at the Experimental Fields of Agronomy Section, Agriculture Research Institute, Tandojam, Pakistan. A three replicated Randomized Complete Block Design (RCBD) was employed to layout the experiment having plot size of $2.5 \mathrm{~m} \times 5 \mathrm{~m}\left(12.5 \mathrm{~m}^{2}\right)$. Four cotton varieties i.e. NIAB-78, Shahbaz-95, Sindh-1 and TH-224/87 were chosen for this study based on their frequent farmer usage. All the agronomic practices were performed according to standard procedures. Results showed that all the growth and yield components of cotton were significantly $(P<0.01)$ affected by varieties and irrigation frequencies with exception of monopodial branches and staple length, which were not significantly $(P>0.05)$ affected by irrigation frequencies. The cotton crop irrigated six times at 21 days interval showed better results with $138.16 \mathrm{~cm}$ plant height, 1.45 monopodial branches per plant, 21.83 sympodial

\footnotetext{
${ }^{*}$ Corresponding author.
}

How to cite this paper: Sahito, A., Baloch, Z.A., Mahar, A., Otho, S.A., Kalhoro, S.A., Ali, A., Kalhoro, F.A., Soomro, R.N. and Ali, F. (2015) Effect of Water Stress on the Growth and Yield of Cotton Crop (Gossypium hirsutum L.). American Journal of Plant Sciences, 6, 1027-1039. http://dx.doi.org/10.4236/ajps.2015.67108 
branches per plant, 44.58 bolls per plant, $33.86 \%$ G.0.T., and $26.97 \mathrm{~mm}$ staple length, $149.84 \mathrm{~g}$ seed cotton yield per plant and $2271.16 \mathrm{~kg} \cdot \mathrm{ha}^{-1}$ seed cotton yield. This study concluded that variety NIAB-78 showed superiority over Shahbaz-95, Sindh-1 and TH-224/87 in almost all the characters of economic importance, and the cotton crop received 6 irrigations at 21 days interval resulted in significantly economical overall performance as compared with 5 irrigations or 4 irrigations with higher seed cotton yield.

\section{Keywords}

Cotton Crop, Drought Stress, Tolerance, Yield

\section{Introduction}

Cotton, Gossypium hirsutum L., is one of the most important fibre crops playing a key role in economic and social affairs of the world. It is a soft fibre that grows around the seeds of the cotton plant Gossypium spp., a shrub native to tropical and subtropical regions around the world, including the Americas, India, and Africa [1]. The fibre is most often spun into thread and used to make a soft, breathable textile, which is the most widely used natural-fibre cloth in clothing today [2]. It is generally believed that the first cultivation of cotton was in India, though it grew wild in several locations around the world. People living in Egypt's Nile Valley and across the world in Peru were also familiar with cotton [3]. The seven largest producers of cotton worldwide are: China, the United States, India, Pakistan, Uzbekistan, Turkey and Brazil, while the five leading exporters are: the United States, the Franc Zone of Africa, Uzbekistan, Australia and India [4].

Cotton is used to make a number of textile products. These include terrycloth, used to make highly absorbent bath towels and robes; denim, used to make blue jeans; chambray, popularly used in the manufacture of blue work shirts and corduroy, seersucker, and cotton twill. Socks, underwear, and most T-shirts are made from cotton. Bed sheets are often made from cotton. Cotton is also used to make yarn used in crochet and knitting. Fabric can also be made from recycled or recovered cotton that would otherwise be thrown away during the spinning, weaving or cutting process [5]. While many fabrics are made completely of cotton, some materials blend cotton with other fibers, including rayon and synthetic fibers such as polyester [1].

Pakistan is predominantly an agricultural country and prosperity of people depends largely upon the successful cultivation of crops like wheat, cotton, rice, sugarcane and maize [6]. Among these, cotton occupies central position because of its substantial foreign exchange earnings (76\%) through export of raw cotton, yarn and finished products [6]. In addition, cotton crop also provides livelihood to millions of people, who are engaged in textile industry directly or indirectly. Realizing role of this crop in building the economy of Pakistan, its yield improvement has always been the objective of extensive research under local environmental conditions and better utilization of sources available for successful crop production [7]. Successful cotton production totally depends upon the availability of irrigation water either from canal or tube well. Irrigated agriculture is facing acute competition for low cost and high quality water [8]. High quality irrigation water is becoming another challenge and the world is looking for water saving agriculture, which refers to full advantage of available irrigation facilities [9]. Water saving agriculture intends to raise water utilization rate and efficiency for achieving a high economic yield on irrigated farm land with minimum input of water at both public and private levels [10].

Proper planning and improved water use is a potential selection criterion for improving yield under water stress and it evaluates the way and depth of water application, whether it was used at optimum level by the crop. Usually cotton crop uses less water per hectare than other crops with exception of horticulture [11]. Effective use of irrigation is not simply a water saving irrigation but it is a comprehensive exercise using every possible water saving measures in farm production, including full use of natural precipitation as well as efficient management of an irrigation network through a suitable planting method. Planting methods are important factor which affects crop growth development and finally the crop yield. Decrease in row spacing increased light interception, growth rate, total biomass production and water use efficiency [12]. Better irrigation water use efficiency can be achieved through adopting the best management practices of irrigation [13]. According to [7], 
adoption of subsurface irrigation on smaller acreage can increase cotton yield, water use efficiency and return per acre. Adoption of appropriate planting method and water management for successful crop production are the most critical problems especially in cotton growing areas of Pakistan [10].

Efficient use of water to a crop is an important consideration where irrigation water resources are limited or diminishing and rainfall is a limiting factor [14]. Additionally, recent increases in energy prices have attracted attention of crop producers asking how to manage inputs to maximize efficiency of their water resources [15]. Regardless of the situation, it is crucial that growers have to get optimum out of every inch of available water, whether it comes through irrigation, rainfall or both [16]. In many countries therefore, strenuous efforts have been made to increase production, mainly by increasing yields through the intensive use of chemical inputs, irrigation and the use of higher-yielding varieties [17].

Among techniques for efficient use of irrigation water, irrigation scheduling has great significance and it is the decision of when and how much water to apply to an irrigated crop to maximise net returns. The maximisation of net returns requires a high level of irrigation efficiency [7]. This requires the accurate measurement of the volume of water applied or the depth of application. It is also important to achieve a uniform water distribution across the paddock to maximise the benefits of irrigation scheduling. Accurate water application prevents over- or underirrigation [11]. Over-irrigation wastes water, energy and labour, leaches nutrients below the root zone and leads to waterlogging which reduces crop yields. Under-irrigation stresses the plant, resulting in yield reductions and decreased returns [11]. To benefit from irrigation scheduling you must have an efficient irrigation system. Waterbalance irrigation scheduling is the day-to-day accounting of the amounts of water coming into and going out of the effective root zone of a crop. It is based on estimating the soil water content in the crop root zone viewed as a system [18].

Keeping in view the importance of efficient use of irrigation water by proper scheduling for cotton production, the present study was carried out to investigate the effect of number of irrigations on the growth and yield of cotton varieties.

\section{Materials and Methods}

The present study was carried out to examine the effect of number of irrigations on the growth and yield of cotton during 2014. The trial was conducted at the Experimental Fields of Agronomy Section, Agriculture Research Institute, Tandojam, Pakistan. A three replicated Randomized Complete Block Design (RCBD) was employed to layout the experiment having plot size of $2.5 \mathrm{~m} \times 5 \mathrm{~m}\left(12.5 \mathrm{~m}^{2}\right)$.

Following the recommendations regarding the land preparation, the experimental land was ploughed up by cross-wise disc plough. After soaking dose, when the land came in condition, the seedbed was prepared by using cultivator (cross-wise) and rotavator (Pakistan Cultivator Manufacturers, Traders and Companies, Lahore, Pakistan). Thereafter, clods were crushed completely by clod crusher followed by planking. Sowing of experimental crop was done on $26^{\text {th }}$ April, 2014. The sowing was done with the help of single coulter hand drill in lines. The treatments were managed in such a way to discriminate the plots of treatments and replications easily and channels and bunds were prepared to facilitate the irrigation process and further monitoring of the crop against any pest problem. Irrigation frequencies was considered as Factor-A, while cotton varieties were assumed as Factor-B to establish experiment. A total of 36 plots were prepared which were distributed in three replicates and in each replicate interactive effect of three irrigation frequencies and four varieties was investigated. The treatments details are given as follows:

\subsection{Treatments}

\subsubsection{Factor-A (3 Irrigation Frequencies)}

$\mathrm{I}_{1}=4$ Irrigations: first irrigation 28 days after sowing and subsequent irrigations at 35 days interval.

$\mathrm{I}_{2}=5$ Irrigations: first irrigation 28 days after sowing and subsequent irrigations at 28 days interval.

$\mathrm{I}_{3}=6$ Irrigations: first irrigation 28 days after sowing and subsequent irrigations at 21 days interval.

$$
\begin{aligned}
& \text { 2.1.2. Factor-B ( } 4 \text { Varieties) } \\
& \mathrm{V}_{1}=\text { NIAB-78. } \\
& \mathrm{V}_{2}=\text { Shahbaz-95. }
\end{aligned}
$$




$$
\begin{aligned}
\mathrm{V}_{3} & =\text { Sindh }-1 . \\
\mathrm{V}_{4} & =\text { TH-224/87. }
\end{aligned}
$$

\subsubsection{Factor- $\mathrm{A} \times \mathrm{B}$ (Treatments Combination)}

$$
\begin{array}{llll}
\mathrm{T}_{1}=\mathrm{I}_{1} \mathrm{~V}_{1} & \mathrm{~T}_{2}=\mathrm{I}_{1} \mathrm{~V}_{2} & \mathrm{~T}_{3}=\mathrm{I}_{1} \mathrm{~V}_{3} & \mathrm{~T}_{4}=\mathrm{I}_{1} \mathrm{~V}_{4} \\
\mathrm{~T}_{5}=\mathrm{I}_{2} \mathrm{~V}_{1} & \mathrm{~T}_{6}=\mathrm{I}_{2} \mathrm{~V}_{2} & \mathrm{~T}_{7}=\mathrm{I}_{2} \mathrm{~V}_{3} & \mathrm{~T}_{8}=\mathrm{I}_{2} \mathrm{~V}_{4} \\
\mathrm{~T}_{9}=\mathrm{I}_{3} \mathrm{~V}_{1} & \mathrm{~T}_{10}=\mathrm{I}_{3} \mathrm{~V}_{2} & \mathrm{~T}_{11}=\mathrm{I}_{3} \mathrm{~V}_{3} & \mathrm{~T}_{12}=\mathrm{I}_{3} \mathrm{~V}_{4}
\end{array}
$$

The chemical fertilizers were also applied as per the recommendations and Nitrogen was applied in the form of Urea (46\%) in three splits. The first dose of nitrogen $(1 / 3 \mathrm{~N})$ was applied at the time of sowing, the second $(1 / 3 \mathrm{~N})$ at the first irrigation and the final $(1 / 3 \mathrm{~N})$ at the time of third irrigation. All Phosphorus in the form of SSP $\left(18 \% \mathrm{P}_{2} \mathrm{O}_{5}\right)$ was applied at the time of sowing. Irrigations were applied as per the schedule. Potassium fertilizer was not applied, as soil was adequate in $\mathrm{K}$. The row spacing maintained at $75 \mathrm{~cm}$ apart and distance between plants was $30 \mathrm{~cm}$. The recommended cultural practices were performed in all the subplots. Five plants in each treatment were selected at random for all the observations. These plants were tagged and numbered separately. The observations were recorded on the following parameters.

\subsection{Observations Recorded}

1) Plant height (cm);

2) Number of monopodial branches per plant;

3) Number of sympodial branches per plant;

4) Number of bolls per plant;

5) Ginning Out-Turn (\%);

6) Staple length (mm);

7) Seed cotton yield plant $^{-1}(\mathrm{~g})$;

8) Seed cotton yield $\left(\mathrm{kg} \cdot \mathrm{ha}^{-1}\right)$.

The observations on the above parameters were recorded on the basis of randomly selected five plants in each plot. These sample plants were labeled with certain coding and reading of the five plants was averaged for replication-wise data. The crop was kept under close monitoring against any insect pests and the help was acquired from the Entomologist (cotton) to identify the insect pests and recommend the insecticide against insects causing damage to the experimental crop. All the quantitative characters of the experimental crop were measured in the field, while for G.O.T. and staple length, the cotton samples from each tagged plant were brought to the laboratory for qualitative analysis.

The data thus collected were subjected to statistical analysis using Analysis of variance technique and LSD (Least Significant Test) to discriminate the superiority of treatment means using Mstat-C Computer Statistical Software.

\subsection{Layout of the Experiment}

\section{Experimental Design: RCBD (Factorial) \\ Replications: 3 \\ Plot Size: $2.5 \times 5 \mathrm{~m}\left(12.5 \mathrm{~m}^{2}\right)$ \\ Irrigation Frequencies: 3}

$\mathrm{I}_{1}=04$ irrigations: first irrigation 28 days after sowing and subsequent irrigations at 35 days interval.

$I_{2}=05$ irrigations: first irrigation 28 days after sowing and subsequent irrigations at 28 days interval.

$\mathrm{I}_{3}=06$ irrigations: first irrigation 28 days after sowing and subsequent irrigations at 21 days interval.

Varieties: 3

$$
\begin{array}{llll}
\mathrm{V}_{1}=\text { NIAB-78 } \quad \mathrm{V}_{2}=\text { Shahbaz-95 } & \mathrm{V}_{3}=\text { Sindh- } 1 & \mathrm{~V}_{4}=\mathrm{TH}-224 / 87 \\
\multicolumn{2}{c}{\text { Treatments Combination }} & & \\
\mathrm{T}_{1}=\mathrm{I}_{1} \mathrm{~V}_{1} & \mathrm{~T}_{2}=\mathrm{I}_{1} \mathrm{~V}_{2} & \mathrm{~T}_{3}=\mathrm{I}_{1} \mathrm{~V}_{3} & \mathrm{~T}_{4}=\mathrm{I}_{1} \mathrm{~V}_{4} \\
\mathrm{~T}_{5}=\mathrm{I}_{2} \mathrm{~V}_{1} & \mathrm{~T}_{6}=\mathrm{I}_{2} \mathrm{~V}_{2} & \mathrm{~T}_{7}=\mathrm{I}_{2} \mathrm{~V}_{3} & \mathrm{~T}_{8}=\mathrm{I}_{2} \mathrm{~V}_{4} \\
\mathrm{~T}_{9}=\mathrm{I}_{3} \mathrm{~V}_{1} & \mathrm{~T}_{10}=\mathrm{I}_{3} \mathrm{~V}_{2} & \mathrm{~T}_{11}=\mathrm{I}_{3} \mathrm{~V}_{3} & \mathrm{~T}_{12}=\mathrm{I}_{3} \mathrm{~V}_{4}
\end{array}
$$




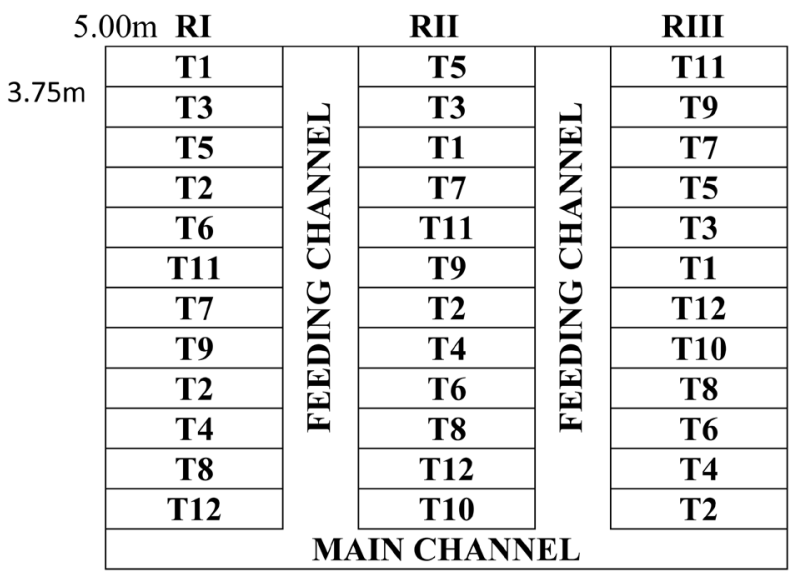

\section{Results and Discussion}

Proper irrigation management in cotton requires assessing irrigation needs by taking measurements of various physical parameters. Some use sophisticated equipment while others use the tried and true common sense approaches. Whichever method used, each has its merits and limitations. The present study was carried out to examine the effect of number of irrigations on the growth and yield of cotton at the Experimental Fields of Agronomy Section, Agriculture Research Institute, Tandojam, Pakistan. Three irrigation scheduling were developed such as: four irrigations, five irrigations and six irrigations, where first irrigation was applied after 28 days of sowing and subsequent irrigations after 35, 28 and 21 days of sowing, respectively. The growth and yield performance of four cotton varieties (NIAB-78, Shahbaz-95, Sindh-1 and TH-224/87) was investigated against different irrigation frequencies. The characters of economic importance such as: plant height, number of mono-


and the results on these characters are reported in Tables 1-8.

Table 1. Average plant height $(\mathrm{cm})$ of cotton varieties as affected by irrigation frequencies.

\begin{tabular}{|c|c|c|c|c|}
\hline \multirow[b]{2}{*}{ Varieties } & \multicolumn{3}{|c|}{ Number of irrigations } & \multirow[b]{2}{*}{ Mean } \\
\hline & $\begin{array}{c}\mathrm{I}_{1}=4 \text { irrigations at } 35 \text { days } \\
\text { interval }\end{array}$ & $\begin{array}{c}\mathrm{I}_{2}=5 \begin{array}{c}\text { irrigations at } 28 \text { days } \\
\text { interval }\end{array}\end{array}$ & $\begin{array}{c}\mathrm{I}_{3}=6 \text { irrigations at } 21 \text { days } \\
\text { interval }\end{array}$ & \\
\hline $\mathrm{V}_{1}=\mathrm{NIAB}-78$ & 111.00 & 124.00 & 135.33 & $123.44 \mathrm{~b}$ \\
\hline $\mathrm{V}_{2}=$ Shahbaz-95 & 121.00 & 133.33 & 145.33 & $133.22 \mathrm{a}$ \\
\hline $\mathrm{V}_{3}=$ Sindh -1 & 119.00 & 133.33 & 137.00 & $129.77 \mathrm{a}$ \\
\hline $\mathrm{V}_{4}=\mathrm{TH}-224 / 87$ & 116.66 & 128.00 & 135.00 & $126.77 \mathrm{~b}$ \\
\hline Mean & $116.91 \mathrm{c}$ & $129.66 \mathrm{~b}$ & 138.16 a & - \\
\hline
\end{tabular}

\begin{tabular}{|c|c|c|c|}
\hline & Irrigations (I) & Varieties (V) & $\mathbf{I} \times \mathbf{V}$ \\
\hline S.E \pm & 1.44 & 1.67 & 1.82 \\
\hline LSD at $\mathrm{P}<0.05$ & 5.525 & 4.203 & - \\
\hline LSD at $\mathrm{P}<0.01$ & 7.746 & 5.893 & - \\
\hline CV\% & 4.94 & & \\
\hline
\end{tabular}

Means with different letter(s) are significantly different. 
Table 2. Average number of monopodial branches per plant of cotton varieties as affected by irrigation frequencies.

\begin{tabular}{|c|c|c|c|c|}
\hline \multirow[b]{2}{*}{ Varieties } & \multicolumn{3}{|c|}{ Number of irrigations } & \multirow[b]{2}{*}{ Mean } \\
\hline & $\begin{array}{c}\mathrm{I}_{1}=4 \begin{array}{c}\text { irrigations at } 35 \text { days } \\
\text { interval }\end{array} \\
\text {. }\end{array}$ & $\begin{array}{c}\mathrm{I}_{2}=5 \text { irrigations at } 28 \text { days } \\
\text { interval }\end{array}$ & 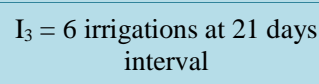 & \\
\hline $\mathrm{V}_{1}=\mathrm{NIAB}-78$ & 1.66 & 1.80 & 2.00 & $1.82 \mathrm{a}$ \\
\hline $\mathrm{V}_{2}=$ Shahbaz-95 & 1.20 & 1.33 & 1.20 & $1.24 \mathrm{ab}$ \\
\hline $\mathrm{V}_{3}=$ Sindh -1 & 1.33 & 1.20 & 1.26 & $1.26 a b$ \\
\hline $\mathrm{V}_{4}=\mathrm{TH}-224 / 87$ & 1.20 & 1.53 & 1.33 & $1.35 a b$ \\
\hline \multirow[t]{2}{*}{ Mean } & 1.30 & 1.46 & 1.45 & - \\
\hline & Irrigations (I) & \multicolumn{2}{|c|}{ Varieties (V) } & $\mathbf{I} \times \mathbf{V}$ \\
\hline S.E \pm & 0.08 & \multicolumn{2}{|l|}{0.09} & 0.07 \\
\hline LSD at $\mathrm{P}<0.05$ & - & \multicolumn{2}{|c|}{0.5156} & - \\
\hline LSD at $\mathrm{P}<0.01$ & - & \multicolumn{2}{|c|}{0.7228} & \\
\hline CV\% & 19.48 & & & \\
\hline
\end{tabular}

Means with different letter(s) are significantly different.

Table 3. Average number of sympodial branches per plant of cotton varieties as affected by irrigation frequencies.



Means with different letter(s) are significantly different.

Table 4. Average number of sympodial branches per plant of cotton varieties as affected by irrigation frequencies.

\begin{tabular}{ccccc}
\hline Varieties & \multicolumn{4}{c}{ Number of irrigations } \\
\cline { 2 - 4 } & $\begin{array}{c}\mathrm{I}_{1}=4 \\
\text { irrigations at } 35 \text { days } \\
\text { interval }\end{array}$ & $\begin{array}{c}\mathrm{I}_{2}=5 \text { irrigations at } 28 \text { days } \\
\text { interval }\end{array}$ & $\begin{array}{c}\mathrm{I}_{3}=6 \text { irrigations at } 21 \text { days } \\
\text { interval }\end{array}$ & Mean \\
\hline $\mathrm{V}_{1}=$ NIAB-78 & 35.00 & 45.00 & 54.00 & $44.66 \mathrm{a}$ \\
$\mathrm{V}_{2}=$ Shahbaz-95 & 31.33 & 36.00 & 42.00 & $36.44 \mathrm{~b}$ \\
$\mathrm{~V}_{3}=$ Sindh-1 & 28.66 & 33.66 & 40.00 & $34.11 \mathrm{~b}$ \\
$\mathrm{~V}_{4}=$ TH-224/87 & 27.66 & 34.00 & 42.33 & $34.66 \mathrm{~b}$ \\
Mean & $30.66 \mathrm{c}$ & $37.16 \mathrm{~b}$ & $44.58 \mathrm{a}$ & - \\
\hline
\end{tabular}




\begin{tabular}{cccc}
\hline & Irrigations (I) & Varieties (V) & $\mathbf{I} \times \mathbf{V}$ \\
\hline S.E \pm & 1.91 & 2.20 & 0.81 \\
LSD at $\mathrm{P}<0.05$ & 4.339 & 6.503 & - \\
LSD at $\mathrm{P}<0.01$ & 6.083 & 9.920 & \\
CV\% & 9.75 & & \\
\hline
\end{tabular}

Means with different letter(s) are significantly different.

Table 5. Average ginning out-turn (G.O.T.\%) of cotton varieties as affected by irrigation frequencies.

\begin{tabular}{cccc}
\hline Varieties & \multicolumn{3}{c}{ Number of irrigations } \\
\cline { 2 - 4 } & $\begin{array}{c}\mathrm{I}_{1}=4 \text { irrigations at } \\
\text { interval }\end{array}$ & $\begin{array}{c}\mathrm{I}_{2}=5 \text { days } \\
\text { irrigations at } 28 \text { days } \\
\text { interval }\end{array}$ & $\begin{array}{c}\mathrm{I}_{3}=6 \text { irrigations at } 21 \text { days } \\
\text { interval }\end{array}$ \\
\hline $\mathrm{V}_{1}=$ NIAB-78 & 32.60 & 34.64 & 36.07 \\
$\mathrm{~V}_{2}=$ Shahbaz-95 & 30.76 & 31.92 & $31.87 \mathrm{~b}$ \\
$\mathrm{~V}_{3}=$ Sindh-1 & 31.18 & 32.25 & 32.25 \\
$\mathrm{~V}_{4}=$ TH-224/87 & 30.60 & 31.95 & 33.18 \\
Mean & $31.28 \mathrm{~b}$ & $32.69 \mathrm{ab}$ & 33.03 \\
\hline
\end{tabular}

\begin{tabular}{|c|c|c|c|}
\hline & Irrigations (I) & Varieties (V) & $\mathbf{I} \times \mathbf{V}$ \\
\hline S.E \pm & 0.21 & 0.24 & 0.199 \\
\hline LSD at $\mathrm{P}<0.05$ & 1.4622 & 1.5846 & 1.5337 \\
\hline LSD at $\mathrm{P}<0.01$ & 2.6480 & 2.8196 & - \\
\hline CV\% & 5.12 & & \\
\hline
\end{tabular}

Means with different letter(s) are significantly different.

Table 6. Average staple length (mm) of cotton varieties as affected by irrigation frequencies.

\begin{tabular}{|c|c|c|c|c|}
\hline \multirow[b]{2}{*}{ Varieties } & \multicolumn{3}{|c|}{ Number of irrigations } & \multirow[b]{2}{*}{ Mean } \\
\hline & $\begin{array}{c}\mathrm{I}_{1}=4 \text { irrigations at } 35 \text { days } \\
\text { interval }\end{array}$ & $\begin{array}{c}\mathrm{I}_{2}=5 \text { irrigations at } 28 \text { days } \\
\text { interval }\end{array}$ & $\begin{array}{c}\mathrm{I}_{3}=6 \text { irrigations at } 21 \text { days } \\
\text { interval }\end{array}$ & \\
\hline $\mathrm{V}_{1}=\mathrm{NIAB}-78$ & 28.17 & 28.02 & 28.28 & $28.16 \mathrm{a}$ \\
\hline$V_{2}=$ Shahbaz-95 & 26.17 & 26.27 & 26.25 & 26.23 bc \\
\hline $\mathrm{V}_{3}=\mathrm{Sindh}-1$ & 27.32 & 27.35 & 27.01 & $27.23 \mathrm{~b}$ \\
\hline $\mathrm{V}_{4}=\mathrm{TH}-224 / 87$ & 26.32 & 26.45 & 26.34 & 26.37 bc \\
\hline Mean & 27.00 & 27.02 & 26.97 & - \\
\hline
\end{tabular}

\begin{tabular}{cccc}
\hline & Irrigations (I) & Varieties (V) & 0.30 \\
S.E \pm & 0.26 & 0.8375 \\
LSD at $\mathrm{P}<0.05$ & - & 1.0732 \\
LSD at $\mathrm{P}<0.01$ & - & & - \\
CV\% & 3.06 & & \\
\hline
\end{tabular}

Means with different letter(s) are significantly different. 
Table 7. Average seed cotton yield per plant (g) of cotton varieties as affected by irrigation frequencies.

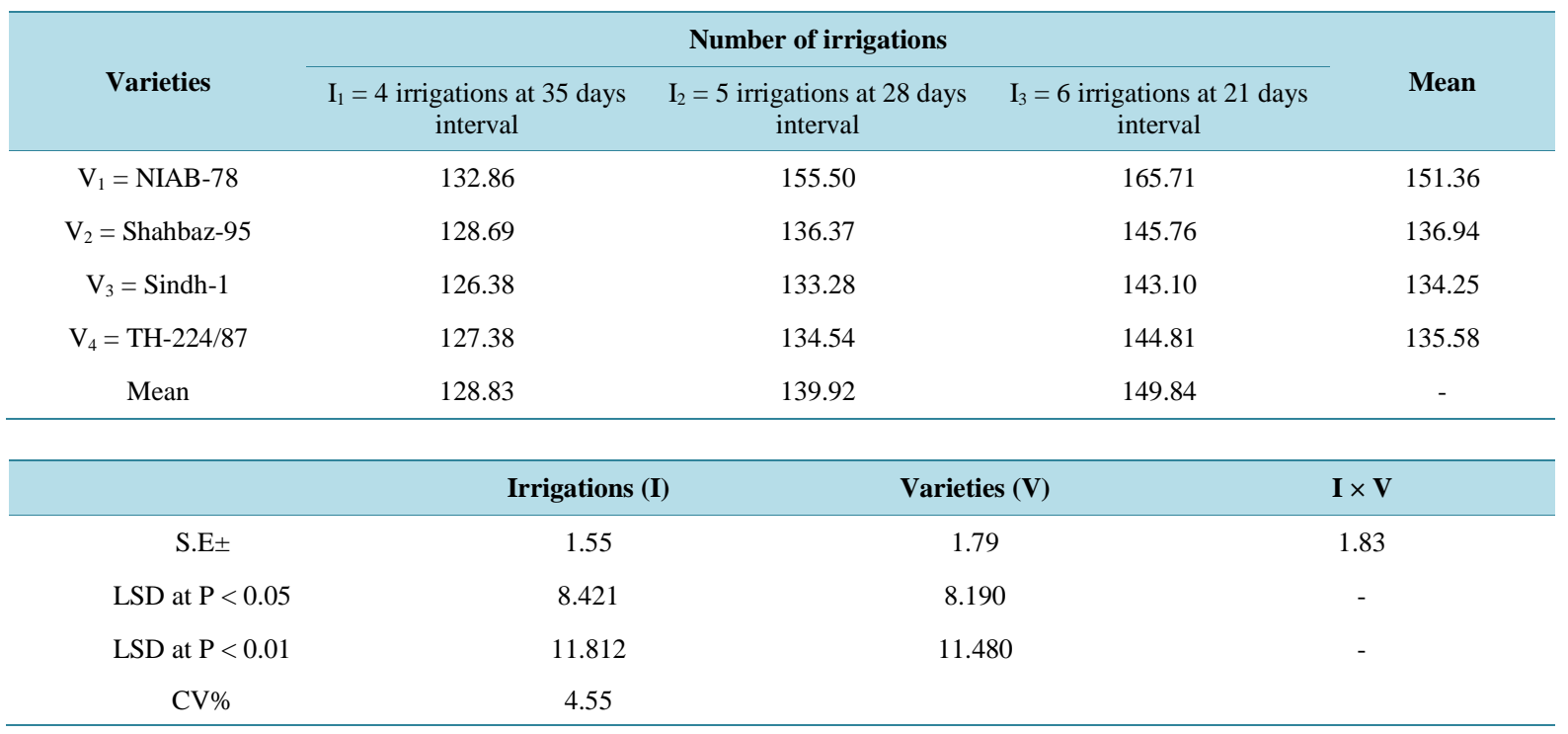

Means with different letter(s) are significantly different.

Table 8. Average seed cotton yield per hectare $(\mathrm{kg})$ of cotton varieties as affected by irrigation frequencies.

\begin{tabular}{ccccc}
\hline \multirow{2}{*}{ Varieties } & \multicolumn{4}{c}{ Number of irrigations } \\
\cline { 2 - 4 } & $\begin{array}{c}\mathrm{I}_{1}=4 \text { irrigations at } 35 \text { days } \\
\text { interval }\end{array}$ & $\begin{array}{c}\mathrm{I}_{2}=5 \text { irrigations at } 28 \text { days } \\
\text { interval }\end{array}$ & $\begin{array}{c}\mathrm{I}_{3}=6 \text { irrigations at 21 days } \\
\text { interval }\end{array}$ & Mean \\
\hline $\mathrm{V}_{1}=$ NIAB-78 & 1436.66 & 2060.66 & 2696.66 & 2064.66 \\
$\mathrm{~V}_{2}=$ Shahbaz-95 & 1219.33 & 1638.33 & 2334.66 & 1730.77 \\
$\mathrm{~V}_{3}=$ Sindh-1 & 1143.33 & 1552.66 & 1976.66 & 1557.55 \\
$\mathrm{~V}_{4}=$ TH-224/87 & 1170.00 & 1591.66 & 2076.66 & 1612.77 \\
Mean & 1242.33 & 1710.83 & 2271.16 & - \\
\hline
\end{tabular}

\begin{tabular}{cccc}
\hline & Irrigations (I) & Varieties (V) & $\mathbf{I} \times \mathbf{V}$ \\
\hline S.E \pm & 27.86 & 32.17 & 31.01 \\
LSD at $\mathrm{P}<0.05$ & 76.34 & 57.58 & 82.05 \\
LSD at $\mathrm{P}<0.01$ & 107.0 & 80.72 & 110.0 \\
CV\% & 6.17 & & \\
\hline
\end{tabular}

Means with different letter(s) are significantly different.

\subsection{Plant Height (cm)}

Plant height is a major growth character in cotton and it is generally influenced by use of various inputs and by genetic makeup of parental material of varieties. The results regarding the plant height of cotton varieties as influenced by various irrigation frequencies are given in Table 1 and the analysis of variance is shown as Appendix-I. The analysis of variance suggested that the plant height was significantly $(\mathrm{P}<0.01)$ affected due to irrigation frequencies and varieties, while non-significant $(\mathrm{P}>0.05)$ due to interaction between irrigation frequencies and varieties.

The plant height of cotton was significantly maximum $(138.16 \mathrm{~cm})$ under six irrigations at 21 days interval, followed by average plant height of $129.66 \mathrm{~cm}$ under five irrigations at 28 days interval and the minimum plant height of $116.91 \mathrm{~cm}$ was recorded when the crop received only four irrigations at 35 days interval. In case of varieties, Shahbaz-95 produced plants of maximum height $(133.22 \mathrm{~cm})$, followed by varieties Sindh-1 and TH- 
224/87 with average plant height of 129.77 and $126.77 \mathrm{~cm}$, respectively. However, the lowest plant height of $123.44 \mathrm{~cm}$ was recorded in commercial high yielding variety NIAB-78. The treatment interactions of 6 irrigations $\times$ variety Shahbaz-95 resulted plant height of $145.33 \mathrm{~cm}$, followed by interaction of 6 irrigations $\times$ variety Sindh-1, while the lowest plant height of $111.00 \mathrm{~cm}$ under 4 irrigations $\times$ variety NIAB-78. It can be assessed from the results that that variety NIAB-78 is dwarf in nature and similar behaviour was exposed by TH-224/87.

\subsection{Number of Monopodial Branches per Plant}

Number of monopodial branches per plant is a character of prime significance in cotton, because development of sympodia is mainly associated with this character. The results in relation to number of monopodial branches of cotton varieties as influenced by irrigation frequencies are reported in Table 2 and the analysis of variance is given as Appendix-II. The results of analysis of variance demonstrated that number of monopodial branches per plant was significantly $(\mathrm{P}<0.01)$ affected by varieties but non-significant $(\mathrm{P}>0.05)$ influence was noted due irrigation frequencies and their interaction with varieties.

The number of monopodial branches per plant was relatively higher (1.46) under five irrigations at 28 days interval, closely followed by six irrigations at 21 days interval with 1.45 monopodial branches, while the minimum number of monopodial branches (1.30) was recorded under four irrigations at 35 days interval. In case of varieties, NIAB-78 put up with maximum monopodial branches (1.82), followed by varieties TH-224/87 and Sindh-1 with 1.35 and 1.26 monopodial branches per plant, respectively. However, the minimum number of monopodial branches (1.24) was recorded in variety Shahbaz-95. It was further noted that the treatment interaction of 6 irrigations $\times$ variety NIAB-78 produced maximum number of monopodial branches (2.00) per plant, followed by interaction of 5 irrigations $\times$ variety NIAB-78, with 1.80 monopodial branches and the lowest number of monopodial branches (1.20) per plant was recorded under varied interactions.

\subsection{Number of Sympodial Branches per Plant}

Sympodial branches are the fruiting bodies that put up with bolls for producing seed cotton and scientifically the number of sympodial branches and number of bolls develop simultaneously. The results relating to number of sympodial branches of cotton varieties as influenced by irrigation frequencies are presented in Table 3, while analysis of variance is shown as Appendix-III. The statistical analysis illustrated highly significant $(\mathrm{P}<0.01)$ effect of irrigation frequencies and varieties on sympodial branches, while non-significant $(P>0.05)$ influence due to interaction between varieties and irrigation frequencies.

The number of sympodial branches per plant was significantly maximum (21.00) under six irrigations at 21 days interval, closely followed by five irrigations at 28 days interval with 20.00 sympodial branches, while the minimum number of sympodial branches (18.58) was noted under four irrigations at 35 days interval. So far the varieties are concerned, NIAB-78 put up with highest number of sympodial branches (24.88), followed by varieties Shahbaz-95 and Sindh-1 with 21.00 and 17.44 sympodial branches per plant, respectively. However, the minimum number of sympodial branches (17.22) was recorded in variety TH-224/87. Treatment interaction indicated that 6 irrigations $\times$ variety NIAB-78 produced maximum number of sympodial branches (27.66) per plant, followed by interaction of 5 irrigations $\times$ variety NIAB-78, with 24.66 sympodial branches and the lowest number of sympodial branches (16.33) per plant was recorded under interaction of 4 irrigations $\times$ variety TH-224/87.

\subsection{Number of Bolls per Plant}

Number of bolls on a plant mounts up the quantity of seed cotton per plant which subsequently accumulates the seed cotton yield per hectare. The results pertaining to the number of sympodial branches of cotton varieties as influenced by irrigation frequencies are indicated in Table 4, and the analysis of variance is given as Appendix-IV. The analysis of variance suggested that number of bolls per plant was significantly $(\mathrm{P}<0.01)$ affected by irrigation frequencies and varieties, while treatment interaction had non-significant $(P>0.05)$ effect on this component.

It is obvious from the results (Table 4) that the number of bolls per plant was significantly highest (44.58) when cotton crop was irrigated six times at 21 days interval during whole of its growth period, followed by five irrigations at 28 days interval with 37.16 bolls per plant, while the minimum number of bolls (30.66) was noted 
under four irrigations at 35 days interval. In varieties, NIAB-78 put up with remarkably maximum number of bolls (44.66) per plant, followed by variety Shahbaz-95 with 36.44 bolls per plant, while the minimum number of bolls i.e. 34.66 and 34.11 per plant was recorded in varieties TH-224/87 and Sindh-1, respectively. Treatment interaction showed that 6 irrigations $\times$ variety NIAB-78 produced maximum number of bolls (54.00) per plant, followed by interaction of 5 irrigations $\times$ variety NIAB-78, with 45.00 bolls and the lowest number of bolls (27.66) per plant was recorded under interaction of 4 irrigations $\times$ variety TH-224/87. The results suggested that the number of bolls per plant was associated with the number of sympodial branches per plant.

\subsection{Ginning Out-Turn (\%)}

While quality of a cotton variety is measured, the ginning out-turn (GOT) is given utmost significance. The results regarding the G.O.T. percent of four cotton varieties as affected by different irrigation frequencies are presented in Table 5 and the analysis of variance to this effect is given as Appendix-V. The results of the analysis of variance showed that the differences in the G.O.T. percent were statistically highly significant due to different varieties, irrigation frequencies $(\mathrm{P}<0.01)$ as well as interaction between varieties and irrigation frequencies $(\mathrm{P}<$ 0.05).

The cotton crop irrigated six times at 21 days interval during whole of its growing period resulted significantly higher G.O.T. of 33.86 percent, followed by five irrigations at 28 days interval with average G.O.T. of 32.69 percent, while the minimum G.O.T. of 31.28 percent was recorded in the plots receiving four irrigations at 35 days interval. Similarly among varieties, NIAB-78 performed remarkably superior with highest G.O.T. of 34.43 percent, followed by 32.20 percent G.O.T. recorded by variety Sindh-1, while lower G.O.T. of 31.87 and 31.86 percent was recorded in varieties Shahbaz-95 and TH-224/87, respectively. The treatment interactions showed that maximum G.O.T. of 36.07 percent was recorded in interaction between 6 irrigations $\times$ cultivar NIAB-78, followed by average G.O.T. of 34.64 percent recorded in treatment interactions between 5 irrigations $\times$ cultivar NIAB-78 and lowest G.O.T. of 30.60 percent was recorded in treatment interaction of 4 irrigations $\times$ cultivar TH-224/87.

\subsection{Staple Length ( $\mathrm{mm})$}

While a cotton variety is evolved, the staple length is considered as the major quality characteristic. The results pertaining to staple length of four cotton varieties as affected by various irrigation frequencies are reported in Table 6 and the analysis of variance is shown as Appendix-VI. The results of analysis of variance demonstrated that the staple length was significantly $(\mathrm{P}<0.01)$ different in cotton varieties, while there was non-significant effect of irrigation frequencies and treatment interaction between varieties and irrigation frequencies on staple length $(\mathrm{P}>0.05)$.

It is evident from the results (Table 6) that staple length was relatively higher $(27.02 \mathrm{~mm})$ in the plots receiving 5 irrigations at 28 days interval, followed by 4 irrigations at 35 days interval having average staple length of $27.00 \mathrm{~mm}$, while the minimum staple length of $26.97 \mathrm{~mm}$ was recorded in plots receiving 6 irrigations at 21 days interval. In case of varieties, NIAB-78 showed its superiority in this quality character with highest staple length of $28.16 \mathrm{~mm}$, followed by $27.23 \mathrm{~mm}$ in variety Sindh-1 and the varieties TH-224/87 and Shahbaz-95 equally had lower staple length of $26.37 \mathrm{~mm}$ and $26.23 \mathrm{~mm}$, respectively. The treatment interactions showed that relatively higher staple length of $28.28 \mathrm{~mm}$ was recorded in interaction between 6 irrigations $\times$ variety NIAB-78, closely followed by the same variety under 5 and 4 irrigations with average staple length of 28.02 and $28.17 \mathrm{~mm}$, respectively. The lowest staple length $(26.17 \mathrm{~mm})$ was recorded in treatment interactions between 4 irrigations $\times$ variety Shahbaz-95. The results suggested that staple length is mainly influenced by genetic factors and probably not by the varied input applications.

\subsection{Cotton Seed Yield per Plant (g)}

The results pertaining to seed cotton yield per plant of four cotton cultivars as affected by different irrigation regimes are presented in Table 7 and the analysis of variance for this variable is given as Appendix-VII. The analysis of variance suggested that differences in seed cotton yield per plant were statistically significant $(\mathrm{P}<$ 0.01 ) for varieties and irrigation frequencies, while non-significant $(\mathrm{P}>0.05)$ for their interactions.

The cotton crop received 6 irrigations at 21 days interval produced significantly highest seed cotton yield per 
plant of $149.84 \mathrm{~g}$, followed by seed cotton yield per plant of $139.92 \mathrm{~g}$ recorded in the crop irrigated five times during the whole of its growing period at 28 days interval, while the minimum seed cotton yield per plant of $128.83 \mathrm{~g}$ was obtained in the crop irrigated four times at 35 days interval. In case of cotton varieties, NIAB-78 proved to be a superior variety with significantly highest seed cotton yield per plant of $151.36 \mathrm{~g}$, followed by varieties Shahbaz-95 and TH-224/87 with average seed cotton yield per plant of $136.94 \mathrm{~g}$ and $135.58 \mathrm{~g}$, respectively. However, the minimum seed cotton yield per plant of $134.25 \mathrm{~g}$ was obtained in plots sown with variety Sindh-1. Results further showed that treatment interaction of 6 irrigations $\times$ variety NIAB-78 produced highest per plant yield (165.71 g), followed by $155.50 \mathrm{~g}$ per plant yield under 5 irrigations $\times$ NIAB-78 interaction and lowest per plant yield of $126.38 \mathrm{~g}$ was recorded in interaction of 4 irrigations $\times$ variety Sindh- 1 .

\subsection{Cotton Seed Yield $\left(\mathrm{kg} \cdot \mathrm{ha}^{-1}\right)$}

The output of a research project on cotton production is appraised from the resultant quantity of seed cotton per unit area. The results relating to seed cotton yield per hectare of four cotton varieties as influenced by different irrigation frequencies are shown in Table 8, while the analysis of variance is given as Appendix-VIII. The analysis of variance illustrated that differences in seed cotton yield per hectare were statistically significant $(\mathrm{P}<0.01)$ for varieties, irrigation frequencies as well as for their interactions.

It was evident from the results that cotton crop irrigated 6 times during whole of its growing period at 21 days interval produced significantly highest seed cotton yield $2271.16 \mathrm{~kg} \mathrm{ha}^{-1}$, followed by yield of $1710.83 \mathrm{~kg} \cdot \mathrm{ha}^{-1}$ recorded in the crop irrigated five times during the whole of its growing period at 28 days interval, while the minimum seed cotton yield per hectare of $1242.33 \mathrm{~kg} \cdot \mathrm{ha}^{-1}$ was recorded in the crop irrigated four times at 35 days interval. In case of varieties, NIAB-78 showed its superiority over rest of the varieties with significantly maximum seed cotton yield of $2064.66 \mathrm{~kg} \cdot \mathrm{ha}^{-1}$, followed by varieties Shahbaz-95 and TH-224/87 with average seed cotton yield of 1730.77 and $1612.77 \mathrm{~kg} \cdot \mathrm{ha}^{-1}$, respectively. However, the minimum seed cotton yield of $1557.55 \mathrm{~kg} \cdot \mathrm{ha}^{-1}$ was recorded in plots sown with variety Sindh-1. It was further noted that interaction of 6 irrigations $\times$ variety NIAB-78 produced highest yield of $2696.66 \mathrm{~kg} \cdot \mathrm{ha}^{-1}$, followed by yield of $2334.66 \mathrm{~kg} \cdot \mathrm{ha}^{-1} \mathrm{un}-$ der interaction of 6 irrigations $\times$ Shahbaz-95 and lowest yield of $1143.33 \mathrm{~kg} \cdot \mathrm{ha}^{-1}$ was recorded in interaction of 4 irrigations $\times$ variety Sindh-1. It was noted that variety NIAB-78 yet showed superiority over Shahbaz-95, Sindh- 1 and TH-224/87, and 6 irrigations are necessarily required by cotton crop for good crop yields.

A sensible planning for efficient use of irrigation is prerequisite for successful crop production, particularly under water stress conditions. Assessment for water requirement of cotton is one of the most significant elements. The present study was carried out to examine the effect of number of irrigations on the growth and yield of cotton at the Experimental Fields of Agronomy Section, Agriculture Research Institute, Tandojam during the year 2007.

In the present study, plant height of cotton was maximum $(138.16 \mathrm{~cm})$ under six irrigations at 21 days interval, variety Shahbaz-95 produced plants of maximum height $(133.22 \mathrm{~cm})$, followed by varieties Sindh-1, TH-224/87 and lowest plant height of $123.44 \mathrm{~cm}$ was recorded in commercial high yielding variety NIAB-78. The results showed that cultivars Shahbaz-95 and TH-224/87 are genetically tall growing, while NIAB-78 was relatively a dwarf cultivar. These results are further supported by [19] and [20] and [21] who were of the opinion that irrigation frequencies has great association with plant height, while different cotton varieties have varied response regarding plant height. Similarly, the number of monopodial branches per plant was relatively higher (1.46) under five irrigations at 28 days interval, while the minimum (1.30) under four irrigations at 35 days interval. In case of varieties, NIAB-78 put up with greater monopodial branches (1.82) than TH-224/87, Sindh-1 and Shahbaz-95. On the other hand, these results are partially supported by [21], who were of the experience that this character generally does not get effect of any treatment, but cultivars of different genetic makeup could have varied number of monopodial branches. Sympodial branches per plant in the present study was higher (21.00) under six irrigations at 21 days interval, while minimum branches (18.58) under four irrigations at 35 days interval. Variety NIAB-78 had higher number of sympodial branches (24.88) than Shahbaz-95, Sindh-1 and TH-224/87 and these results are in line with those of [22], stated that irrigation regimes affect sympodial branches significantly, while cotton cultivars of different genetic groups could produce great variation in the number of sympodial branches.

In the present investigation, the number of bolls per plant was significantly higher (44.58) under 6 irrigations at 21 days interval than five irrigations and four irrigations. NIAB-78 had greater number of bolls (44.66) per plant than variety Shahbaz-95, TH-224/87 and Sindh-1. These results in concurrence with those of [14] who 
were of the experience that adequate number of irrigations to a cotton crop would ensure better boll formation and development. Moreover, number of bolls has been considered a genetic parameter and different varieties could have varied number of bolls.

Among quality characteristics, the G.O.T. was significantly higher (33.86 percent) under six irrigations at 21 days interval than rest of the irrigation frequencies; while among varieties NIAB-78 remained superior with higher G.O.T. of 34.43 percent than Sindh-1, Shahbaz-95 and TH-224/87. The results of the present investigation are further confirmed by those [21] and [20], who have reported that G.O.T. is generally not influenced by irrigation frequencies, and this character is directly associated with the genetic makeup of a variety. In the present study, the staple length was relatively higher $(27.02 \mathrm{~mm})$ under 5 irrigations at 28 days interval than 4 irrigations and 6 irrigations; while variety NIAB-78 showed its superiority over Sindh-1, TH-224/87 and Shahbaz-95. These results are in line with those of [20]-[23] who concluded that staple length was not influenced by irrigation frequencies, and this character is probably associated with the genetic makeup of a variety.

Seed cotton yield was significantly higher $\left(2271.16 \mathrm{~kg} \cdot \mathrm{ha}^{-1}\right)$ under 6 irrigations at 21 days interval than five or four irrigations at certain intervals; while variety NIAB-78 showed its superiority over Shahbaz-95, TH-224/87 and Sindh-1. These results are well comparable with the findings reported by [21] [23] [24], who have concluded that irrigating cotton crop with moderate volume will serve the purpose from economic view point and excessive use of water may be avoided. Moreover, they observed that varieties with different genetic make produce different results for yield.

\section{Conclusion}

In order to examine the effect of number of irrigations on the growth and yield of cotton varieties, the study was carried out at the Experimental Fields of Agronomy Section, Agriculture Research Institute, Tandojam, Pakistan. Three irrigation scheduling (4, 5 and 6 irrigations), where first irrigation was applied after 28 days of sowing and subsequent irrigations after 35, 28 and 21 days of sowing, respectively. The growth and yield performance of four cotton varieties (NIAB-78, Shahbaz-95, Sindh-1 and TH-224/87) was investigated against different irrigation frequencies. The observations were recorded on plant height, number of monopodial branches, sympodial branches plant ${ }^{-1}$, number of bolls plant ${ }^{-1}$, Ginning Out-Turn, staple length, yield ha ${ }^{-1}$. It was concluded that variety NIAB-78 showed superiority over Shahbaz-95, Sindh-1 and TH-224/87 in almost all the characters of economic importance, and the cotton crop received 6 irrigations at 21 days interval resulted in significantly economical overall performance as compared to 5 irrigations or 4 irrigations and produced high seed cotton yield.

\section{References}

[1] Zachary, G.P. (2007) Out of Africa: Cotton and Cash. The New York Times.

[2] Dumka, D., Bednarz, C.W. and Maw, B.W. (2004) Delayed Initiation of Fruiting as a Mechanism of Improved Drought Avoidance in Cotton. Crop Science, 44, 528-534. http://dx.doi.org/10.2135/cropsci2004.5280

[3] Dorothy, M. and Stolton, S. (2001) Organic Cotton: From Field to Final Product. 1-21.

[4] Srinivasan, K. (2006) Bronze Age Trade and Writing System of Meluhha. 8.

[5] Banks, J.C. (2000) Alleviating Stresses for Better Yield. Cotton Farming Home, 1-9. http://www.okstate.edu/ag

[6] Anonymous (2005) Pakistan Economic Survey, Government of Pakistan. Finance Division, Economic Advisor's Wing, Islamabad, 11.

[7] McAlavy, T.W. (2004) Researchers Investigate Cotton Irrigation Strategies. Agricultural Communications Taxas A \& M University System.

[8] Howell, T.A. (2001) Enhancing Water Use Efficiency in Irrigated Agriculture. Agronomy Journal, 93, $281-289$. http://dx.doi.org/10.2134/agronj2001.932281x

[9] Deng, X.-P., Shan, L., Zhang, H.P. and Turner, N.C. (2004) Improving Agricultural Water Use Efficiency in Arid and Semiarid Areas of China. New Directions for a Diverse Planet. Proceeding of the 4th International Crop Science Conference, Brisbane.

[10] Bhattarai, S.P. (2005) The Physiology of Water Use Efficiency of Crops Subjected to Subsurface Drip Irrigation, Oxygation and Salinity in a Heavy Clay Soil. Ph.D. Thesis, School of Biology \& Environmental Science, Faculty of Arts, Health \& Science, Central Queensland University, Rockhampton.

[11] Hearn, B. (2000) The Science of Water Balance: Why Do We Need to Know? Proceedings of the 10th Australian Cot- 
ton Conference, Brisbane, 16-18 August 2000, 351-360.

[12] Staggenborg, S.A., Krieg, D.R. and Harris, J.L. (1992) Water, Nitrogen and Radiation Use Efficiency of Cotton Production Systems. Proceedings of the Beltwide Cotton Conferences, 3, 1029-1030.

[13] Goyne, P.J. and McIntyre, G.T. (2001) Improving on Farm Irrigation Water Use Efficiency in the Queensland Cotton and Grain Industries. A Project of QDPI, Agency for Food and Fiber Sciences, Farming System Institute and Australian Cotton CRC.

[14] Ertek, A. and Kanber, R. (2001) Effects of Different Irrigation Programs on the Growth of Cotton under Drip Irrigation. Turkish Journal of Agriculture and Forestry, 25, 415-425.

[15] Varlev, I., Popova, Z. and Gospodinov, I. (2000) Furrow Surge Irrigation as a Water Saving Technique. Water and the Environment: Innovation in Irrigation and Drainage. Proceedings of the 1st Inter-Regional Conference, Lisbon, 16-18 September 1998, 131-139.

[16] Hood, S. (2002) Rural Water Use Efficiency. Real Water Use Efficiency and the Opportunity. Proceedings of the 11th Australian Cotton Conference, Brisbane, 13-15 August 2002, 285-295.

[17] Nadanassababdy, T. and Kandasamy, O.S. (2002) Effect of Chemical and Cultural Weed Control on Nutrient Removal by Cotton and Associated Weeds. Indian Journal of Weed Science, 34, 316-317.

[18] Harris, G. (2005) Irrigation Water Balance Scheduling. AFFS Farming Systems, DPI and Staff of Australian Cotton Cooperative Research Centre, 1-5.

[19] Patel, P.G., Patel, D.M. and Patel, U.G. (1995) Response of Cotton G.Cot.Hy.8 to Irrigation Based on IW/CPE Ratio. Gujarat Agricultural University Research Journal, 20, 143-145.

[20] El-Shahawy, M.I.M. and Abd-El-Malik, R.R. (2005) Response of Giza 87 Cotton Cultivar Gossypium barbadense L. to Irrigation Intervals and Nitrogen Fertilization Levels. Egyptian Journal of Agricultural Research, 77, 841-856.

[21] Abdel-Malak, K.K.I. and Radwan, F.E. (1998) The Proper Irrigation Intervals for Vegetative and Fruiting Stages of Cotton Cultivar Giza 83. Egyptian Journal of Agricultural Research, 76, 765-772.

[22] Pedroza, S.A. and Flores, A. (1998) Effect of Irrigation, Sowing Methods, and Dosages of Organic Matter on the Control of Phymatotrichum omnivorum in Cotton. Revista Chapingo: Serie Ingeniería Agropecuaria, 1, 29-32.

[23] Rajput, H.A. (2006) Effect of Different Irrigation Regimes on the Performance of Different Cotton Cultivars. Master’s Thesis, Sindh Agriculture University, Tandojam.

[24] Enciso, J.M., Unruh, B.L., Colaizzi, P.D. and Multer, W.L. (2003) Cotton Response to Subsurface Drip Irrigation Frequency under Deficit Irrigation. Applied Engineering in Agriculture, 19, 555-558.

http://dx.doi.org/10.13031/2013.15319 